\title{
Vertical Displacement of the Surface Area over the Leakage to the Transverse salt Mine in 1992-2012
}

\author{
Tomasz Lipecki ${ }^{1, *}$ \\ ${ }^{1}$ AGH University Science and Technology, Faculty of Mining Surveying and Environmental \\ Engineering, A. Mickiewicza Av. 30, 30-059 Krakow, Poland
}

\begin{abstract}
The leakage of water in the salt mine caused considerable deformation of the surface. This article shows the vertical displacement in the area of leakage to the mine excavation, measured by precision leveling, carried out from the first days of leakage in 1992 until 2012. The geological and hydrogeological conditions of the mine, as well as the associated water hazards were described, which in conjunction with the inconvenient location of the excavation site in the northern frontage of the Carpathians and also inadequately conducted mining operations, contributed to the risk of flooding mine. The analysis of the vertical movements of the surface - subsidence and uplift - were present as well as the process of formation of the depression trough in the form of maps and graphs. The analyzes were based on 49 measurement series, starting from the first days of the disaster within the next 20 years. The course of development of the depression trough and the condition of the surface after stopping the water from the rock mass has been shown, which caused the surface to uplift. Key words - salt mining, surveying, subsidence monitoring.
\end{abstract}

\section{Introduction}

Salt mining has been operating in Poland for more than seven centuries, starting with excavations near the surface of the earth and now reaching below 1000 meters below the surface level. Due to the mining activity, which particularly violate the surface of the rock, it presents a great deal of danger. The catastrophic leakage of water along with rock material into the mining pit of one of the mines is the proof of that. Minor spills have been occurring in this area for more than 100 years, therefore the geological-mining service was aware of the existing threat, that was associated with the breach of the protective plaster mine by mining activities prior to the age. In spite of this, no one predicted such a catastrophic leak in 1992, which caused massive damage beneath the surface, flooding and destroying some of the mines in the historic mine, and also in areas where rapid deformation have emerged. In 2012 the 20th anniversary of this event took place, which allowed to do some analyzes covering this period of time and a summary of revealed process of the surface deformation. This article focuses on the vertical surface movements which are one of the basic indicators of deformation. The area where the depression trough has developed has been monitored

\footnotetext{
* Corresponding author: lipecki@agh.edu.pl
} 
and its growth dynamics has been observed in almost 50 series of elevation observations of precision levelling on a network of controlled points, which were established for this purpose, covering the area in question. Based on them, the course of the deepening of the depression trough and the present state of the surface of the area is presented, the same as in 2012 , in which practically no vertical movement of the surface was observed.

\section{Characteristics of the mine area - a historical outline of the transverse area}

In the course of 700 years of operation, the salt mine carried out mining operations at 9 levels reaching $327 \mathrm{~m}$ below the earth's surface. 26 shafts were drilled, around 2050 chambers and over $300 \mathrm{~km}$ of excavations. The volume of selected voids is approximately 7.5 million $\mathrm{m}^{3}$. Some of the excavations from level I to I were considered historic and were protected by creating a historical zone. Depth of the deposit is from 30 to $330 \mathrm{~m}$ below the surface and the thickness is up to $400 \mathrm{~m}$. The salt layer can be divided into two contrasting parts: a solid layer in the higher parts and the layer below a deck. The first structure (at a depth of 60-140 $\mathrm{m}$ below the surface) are solids of salt composed of various shapes and sizes, distributed irregularly in the rock. And this is where the oldest chambers and historical part of the mine are located. The deck layer is strongly corrugated, with layers of salt of different lithium with ganglionic rocks. Figure 1 shows a geological section through the layer.

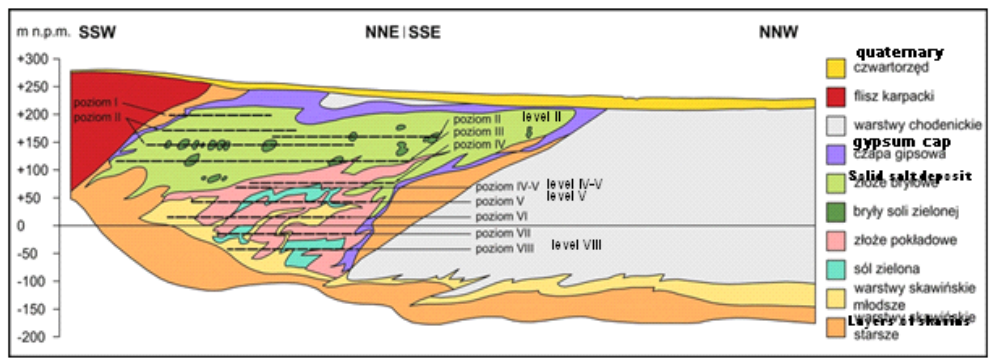

Fig. 1. Geological section through the central part of the deposit [1]

The most important rule in salt mining is to prevent the formation of hydraulic contacts between the mining excavations and the water stored in the rocks. The natural cover in this area are loamy anhydrite chalk, which together with so-called the igneous rock around the reservoir are a natural dam to protect the layer from water from the tertiary waters of the area, which are consisting of the stratocycles, consisting mainly of sandstones filled with deep water, migrating between the upper layers of the salt deposit [2]. Then there are also tributaries of the surface and subsurface layers of the Quaternary. They also come through the shafts and the slits in the rock. Such unfavorable hydrogeological conditions, together with some mining works that broke the insulation decades ago, have allowed uncontrolled water inflows to the mine [3]. This threat is connected with the phenomenon of suffication, consisting in leaching and flushing of rock particles from water permeable rocks, mainly dusty, resulting in the formation of underground channels and caverns, which weaken the stability of the rock surrounding the excavation.

Discussed crosswise was a excavation already hollowed in the nineteenth century at a depth of $150 \mathrm{~m}$ below the surface and was about $400 \mathrm{~m}$ long, forming a research pavement and then transformed to the transporting one. Unfortunately, the final section of the crosswise, at a length of 15 meters, went beyond the boundaries of the layer, thus piercing the gypsum plaster cast, which secured the layer from aquifer tertiary deposits. Over the excavation are chambers operated in the nineteenth and twentieth centuries, and few in the upper levels. 


\section{Disaster in the transverse}

The damage of the protective layer in the transverse has opened the hydraulic connection with the waters in the sandstones of chodenite layers already in 1910. Leakage was not eliminated, due to the small inflow, but constant monitoring of this phenomenon was implement. By 1992, about 226 thousand $\mathrm{m}^{3}$ of water were imported to the mine. Despite the decline of water supply, the water still penetrated lower levels, washed out cavities and cracks, and threatened uncontrolled leakage. This contributed to the decision to carry out security work in the form of liquidation of the leak. Since 1990 covering the leakage has started, but was performed with some interruptions, related to the elimination of voids and croaks around the transom. In 1992 there was a sudden and uncontrolled leakage of variable efficiency, reaching up to $330 \mathrm{l} / \mathrm{min}$. The outflow appeared in various places and was a mixture of fresh water with silt, sand and clay content (Fig. 2).

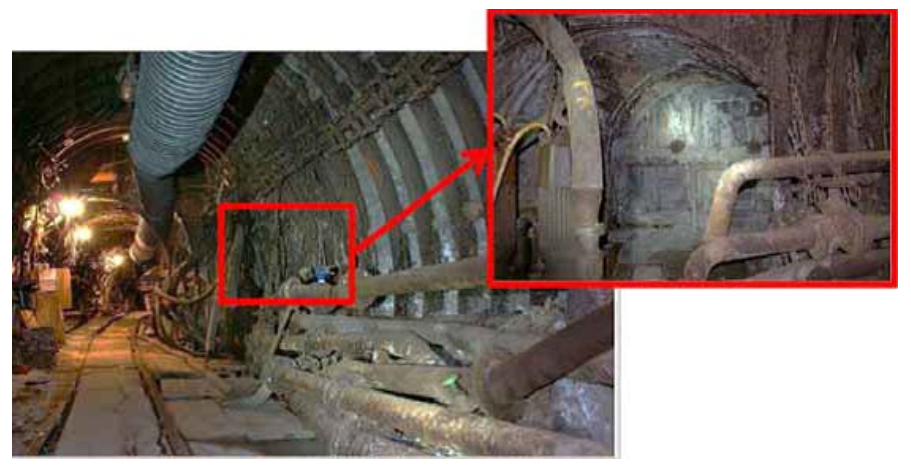

Fig. 2. Place of transverse leakage

In spite of the rescue operation, it was not possible to fully protect the tributary and one month later another flow occured and reached $5000 \mathrm{l} / \mathrm{min}$ and on 30 September it reached even $20000 \mathrm{l} / \mathrm{min}$. It was only after several months that the inflow decreased and stabilized at the level of $1.5 \mathrm{l} / \mathrm{min}$, which made it possible to build a dam about $7 \mathrm{~m}$ from the transverse face. Unfortunately, this caused the waters to pile up behind the dam and generated further water repellents until 1994 when the leak was successfully managed.
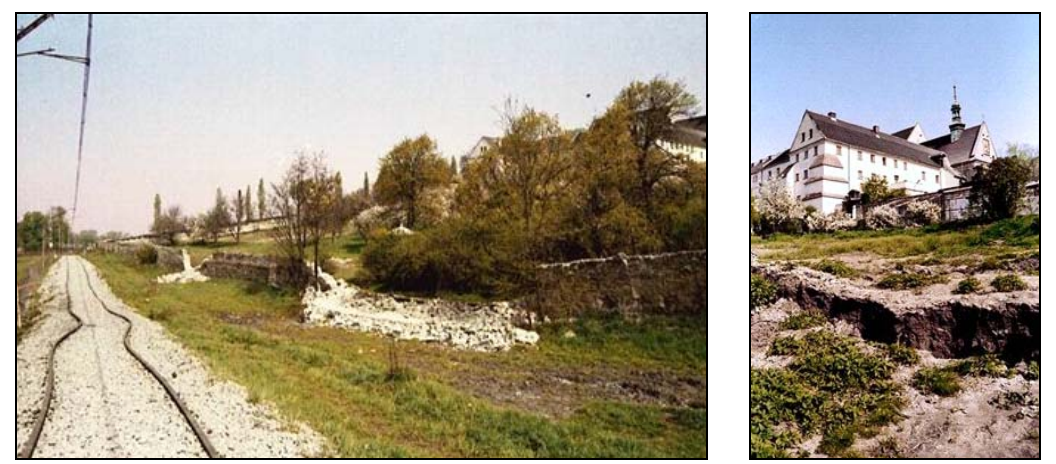

Fig. 3 Deformation of the track and destruction of the wall and cracking of the soil in the monastery's garden [4]

Water supply to the transom was the largest and catastrophic leakage of water into the mine, and could have destroyed it. It caused many losses and damage, and the multi-month struggle for survival of the mine was enormous. Water rapidly penetrated the lower excavations, 
practically destroying level IX, which was eventually liquidated by flooding. Water flooding the mine also threatened the city located above the mine. As a result of the disaster, significant deformations occurred on the northern front of the mine, and after a spill in 1992, a subsidence of a $0.3 \mathrm{~m}$ drop was observed, which deepened at an extremely fast rate from day to day. The trough covered by its impact railways and threatened the buildings of the nearby monastery, eventually causing the wall to collapse. (Fig. 3). These spots are located north of the transverse front, which indicates the size of the area covered by the water inflow. Figure 4 shows the surface deformation in relation to the transverse run that is visible at the bottom of the picture.

Immediately, after the inflow was revealed, protective work was started, which was based not only on the execution of the dam but also on the drilling of wells [3, 5]. Observation wells and subsequent ones forming the so-anti-filter and injection barrier [4]. Due to the unsatisfactory effectiveness of these activities in 1993, the drainage holes of the dam were made and the rock injections were started by drilling around the transverse in the so-called. "Range". In total, 102 injection holes were drilled, including almost $2000 \mathrm{~m}^{3}$ of mortar ore. By the year 2000, the outflow stabilized at around $120 \mathrm{l} / \mathrm{min}$, similarly saturated $\mathrm{NaCl}$ to about $3 \mathrm{~g} / \mathrm{l}$ and insoluble (from $240 \mathrm{~g} / \mathrm{l}$ to $10 \mathrm{~g} / \mathrm{l}$ ).

\section{Surveying monitoring}

During the catastrophic effects of leakage, a number of studies based on geophysical measurements, such as gravimetric and electrofusion, were conducted. However the most frequently performed tests were surface deformation measurements in the form of precision leveling on an established control network [6] covering the extent of the fallen depression from September 1992. For the control of successive states also used InSAR [7] and laser scanning [8]. Initially, the network consisted of 55 ground points distributed regularly every $50 \mathrm{~m}$ and two wall-mounted repairs on the walls of the monastery. After further flows of water, the net was enlarged in the north and east direction and was thicken to a mesh of $25 \mathrm{~m}$ as well as a number of wall markers were stabilized in the surrounding buildings (Fig. 4).

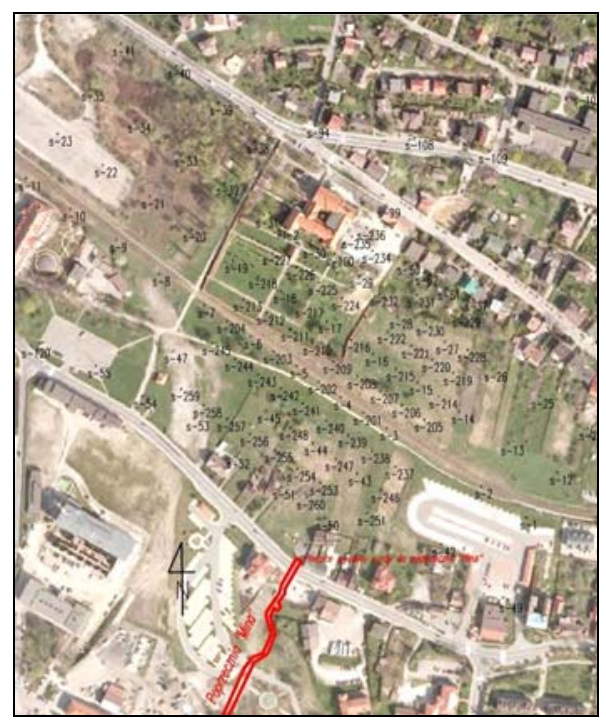

Fig. 4. Location of observation points of fallen trench along the course of transverse

These points were also stocked with precision centering marks for performing situational measurements. Due to the renovation of the railway network, the redevelopment of the 
deformed area in the following years was destroyed but some of the points survived, allowing the analysis of surface changes, for over 20 consecutive years after the catastrophe in the transverse, which is presented in this article.

Initially, the height of the points were determined at several intervals (June - October 1992), then monthly, later quarterly (November 1992 - September 1994) and after calming the impact, as the surface movements ceased, observations are made once per year since 1995 . Average errors in point height $( \pm 0.5-2 \mathrm{~mm})$ were obtained by referencing the network to a fixed repertoire, which was set $3.5 \mathrm{~km}$ away from the deformation region and later referring to GPS points, which also served as reference for angular linear measurements. In this way, the spatial coordinates for some parts of the points, with the accuracy of $\pm 3 \mathrm{~mm}$, were obtained. In total, between 1992 and 2012, 49 series of researches and several series of situational measurements were carried out, which allowed to perform a number of analyzes of the phenomenon of deformation at the discussed area throughout the 20 years.

\section{Analysis of the results of conducted measurements}

Initial measurements from June to September 1992 showed no significant changes in the surface area. Maximum reductions reached $22 \mathrm{~mm}$ in the two points of the observation network during that time. A sudden vertical displacement occurred at the beginning of September as a consequence of another rapid flooding of the water to the transverse, along with a large amount of rock material. The largest subsidence within 4 days reached almost $40 \mathrm{~cm}$, and in the following week increased by another $21 \mathrm{~cm}$. The situation of the depression formed at that time is shown in Figure 5. The reduction covered almost 3 ha and its volume amounted to over $3,800 \mathrm{~m}^{3}$, which gives an idea of the amount of material displaced in the transverse region.
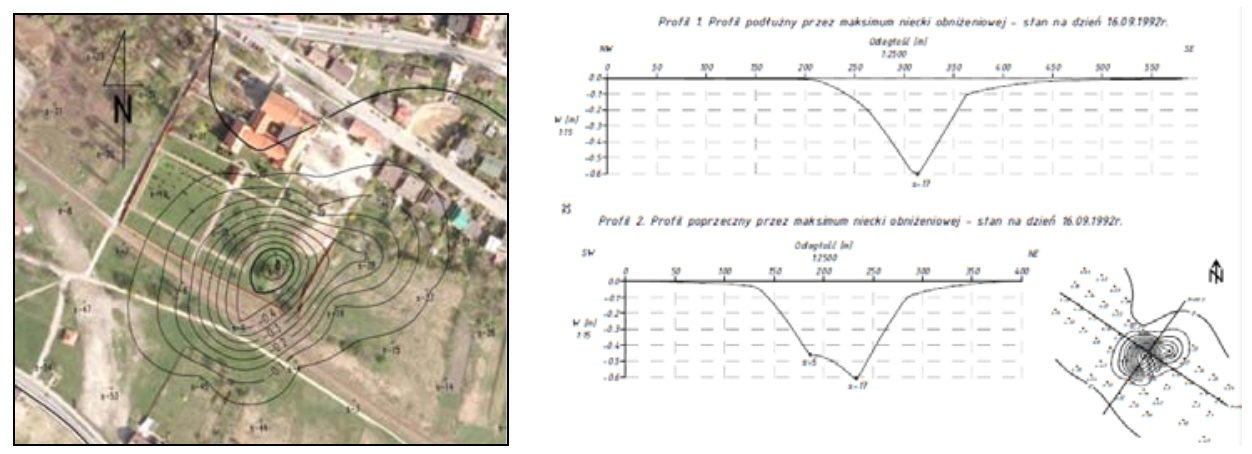

Fig. 5. Subsidence basin -September 1992

Over the next month, the surface moved twice, resulting in further deepening of the subsidence. At its lowest point, the decrease was registered at $1.5 \mathrm{~m}$. Till April 1993, no surface movements had been registered and the recorded monthly cycles of deepening of the area had a value of several millimeters.

At the end of April 1993 there was another sudden spill, causing the trough to deepen to $2 \mathrm{~m}$. After this incident the area was settling at an uneven speed until the end of 1994, when it was mastered and the leak was closed. The map below (Fig. 6) shows the state of deformation in 1995, after mastering the leakage. The trough covers an area of almost 8 hectares and its volume reaches $30000 \mathrm{~m}^{3}$. The largest decreases occur all the time at the same point of the observation network, reaching the value of $2.3 \mathrm{~m}$. The comparison of the spatial shapes of the basin from 1992 and 1995, when recorded its greatest development, is presented in Figure 7. 

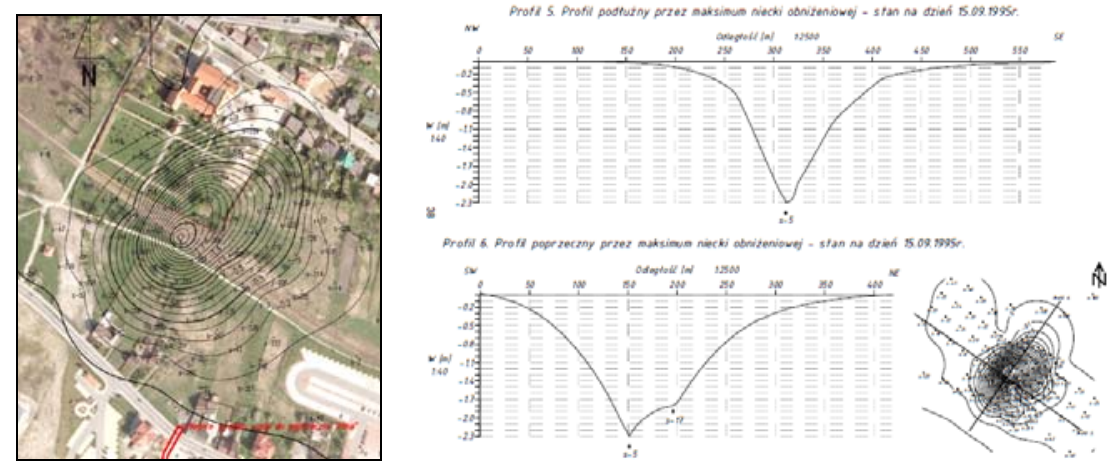

Fig. 6. Subsidence basin - state for 1995, after mastering the leak

Since the leak has been mastered, geodetic measurements have been started in annual cycles. For the next 15 years, the area did not show any significant vertical movements, and the subsidence returned to pre-disaster levels of several mm per year.

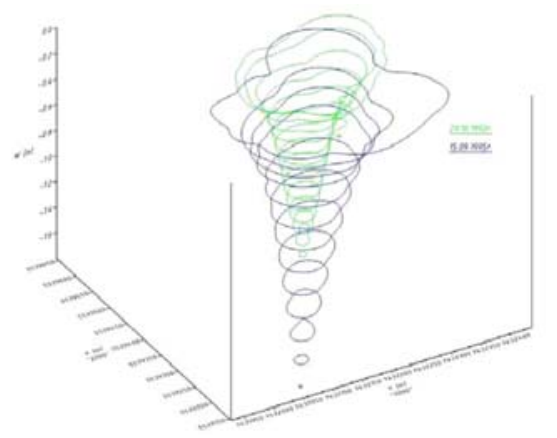

Fig. 7. The development of the subsidence basin in 1992-1995

Figure 8 shows the state of the subsidence basins of the 2012 subsidence. Long-term and slow summation of the reductions has led to the expansion of the basin to more than 12.5 hectares and its volume has increased to almost $37,000 \mathrm{~m}^{3}$. The center of the basin has decreased by an estimate of about $2.4 \mathrm{~m}$ (unfortunately the point of the network has been damaged).
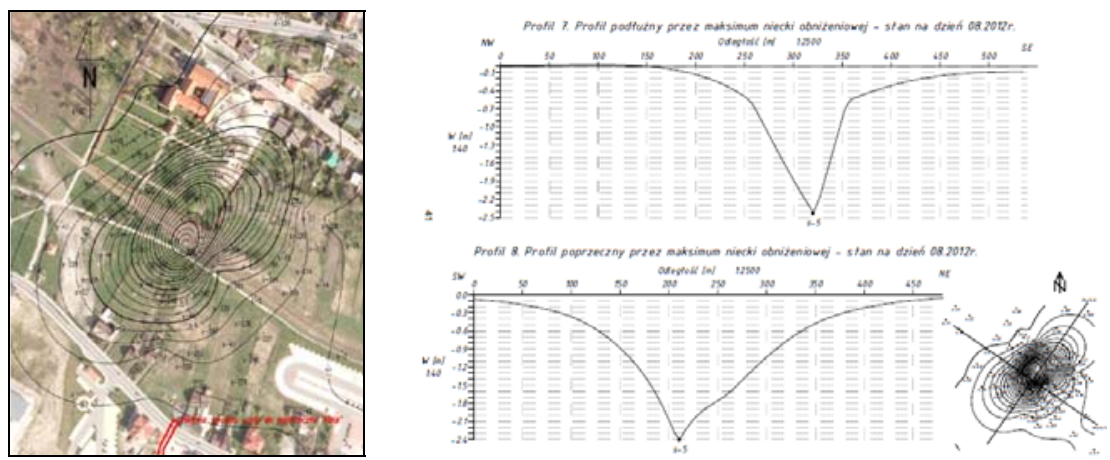

Fig. 8. Subsidence basin - August 2012

The 2012 series did not show any real reductions compared to 2011, but began to observe, since 2007, a few millimeters uplifts, significant from the point of the accuracy of the 
observations. It has been reported even in the years 2007-2008 that the uprising reached up to $20 \mathrm{~mm}$. This is probably due to the rebuilding of the water column in the ground, after the water has completely stopped draining from the front of the transverse dam [9]. The following years of observations confirmed the revealed tendency to rise at an average of several $\mathrm{mm}$ per year in the discussed area. On the map shown in Figure 9, the summary uplifts from 2007 to 2012 are shown, reaching up to $50-70 \mathrm{~mm}$, which suggests that the average annual value of the uplifts oscillates within $10 \mathrm{~mm} / \mathrm{year}$. The centers of reductions and uplifts initially overlapped, but later the maximum uplift shifted north.
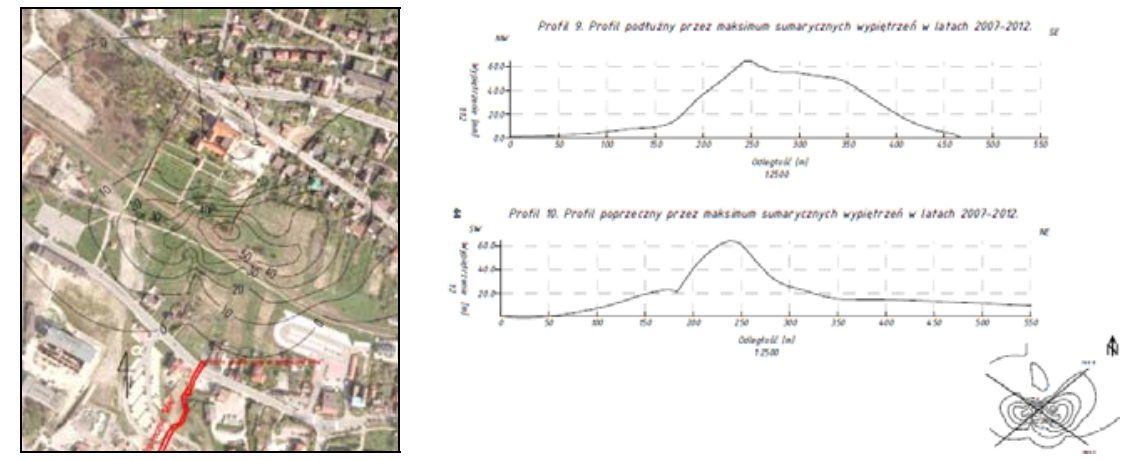

Fig. 9. Uplifts recorded in the period 2007-2012

The nature of elevation changes can be shown not only on the basis of surface analysis. Very good dynamics of changes are reflected in the graphs, that show the behavior of individual points of the research network. The first period, when catastrophic changes occurred (1992), presents a graph of changes in the height of one of the points shown in Figure 10a, and 10b presents the reductions over the period of 20 years (1992-2012). On the first one, there is a visible, instantaneous process of revealed deformation, however after this period, the reductions take a character similar to the curve striving for, almost asymptotically, zero altitude changes. The end of this curve is again increasing and as mentioned before, it presents the process of upliftment, which as you can see, is not a random phenomenon.

a)

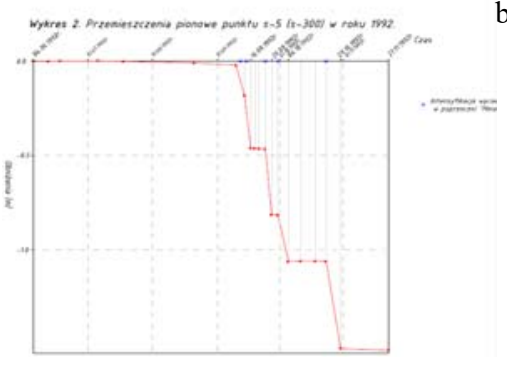

b)

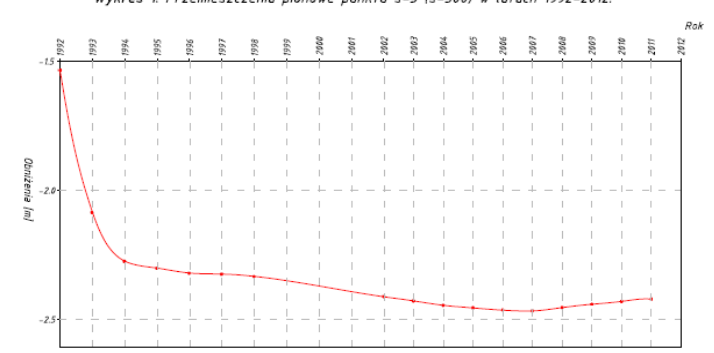

Fig. 10. The dynamics of reduction points in 1992 (a) and during the period 1992 to 2012 (b)

\section{Conclusions}

The leakage in the salt mine was, so far, the biggest disaster the mining service had to face, threatening the mine's existence (primarily historic excavations listed at the UNESCO) and the city because of the deformations, that threatened nearby monastery and destroyed the railroad track. All vertical movements observed on the surface were preceded by intense leaks into the transverse, thus the largest land degradations were recorded between 1992 and 1994. 
The character of that process was irregular with a settling velocity of several to several hundred $\mathrm{mm}$ per day. In the following years the orogen calmed down and the subsidence returned to the typical values of salt orogen. Since 2007, a regular uplift of the surface has been observed, covering almost the whole area of the uplift, which is probably related with the restoration of the natural hydrogeological conditions, after stopping dewatering the transverse. A similar phenomenon is also reported in the paper [10], in which is characterized the uplift of the rock with high permeability and low mechanical stiffness, which activates after a few months of injection. Based on the recent measurement cycles, it can be stated that the ground movements are small now and do not pose a threat to the infrastructure rebuilt on it, but the reductions and uplifts that still appear, indicate that the orogen is constantly subjected to processes which are associated with the reaction to the violation of its structure.

\section{Acknowledgements}

The research was financed by statutory fund WGGiIŚ: 11.11.150.195, AGH University.

\section{References}

1. A. Garlicki, A. Szybist: Ogólne założenia dla zabezpieczenia kopalni Soli Wieliczka oraz nowy obraz geologiczny złoża wielickiego. Likwidacja zagrożenia wodnego dla zabezpieczenia kopalni Soli Wieliczka, III spotkania PSGS, Wieliczka, (1995)

2. K. D’Obyrn, K. Brudnik: Ograniczenie zagrożenia wodnego przez stabilizacje górotworu w centralnym rejonie kopalni ,, Wieliczka”, Górnictwo i Geologia, t. 7, z. 4, (2012)

3. W. Stachoń: Likwidacja największego w historii kopalni soli Wieliczka zagrożenia wodnego, Reinforcement and sealing of rock and construction at the beginning of 21 st century, VSB, conference matterials, Ostrava 15-16.02. (2001)

4. K. Brudnik, J. Przybyło: Historia katastrofy, prowadzonych prac ratunkowych i inżynieryjno-technicznych zmierzajacych do likwidacji zagrożenia kopalni i powierzchni, WEB presentation: http://slideplayer.pl/slide/2795853/, (2008)

5. A. Gonet, K. Brudnik, S. Stryczek: Zabezpieczenie Kopalni Soli „Wieliczka przed zagrożeniem wodnym w otoczeniu poprzeczni ,Mina”, Bezpieczeństwo Pracy i Ochrona Środowiska w Górnictwie, Miesięcznik WUG, nr 12 (40), (1997)

6. G. Kortas (red.): Ruch górotworu i powierzchni w otoczeniu zabytkowych kopalń soli, Wydawnictwo Inst. Gosp. Surowcami Mineralnymi i Energią PAN. Kraków, (2004)

7. Z. Perski, R. Hanssen, A. Wojcik, T. Wojciechowski: InSAR analyses of terrain deformation near the Wieliczka Salt Mine, Poland, Engineering Geology 106 pp. 58-67, www.elsevier.com/locate/enggeo, (2009)

8. T. Lipecki, W. Jaśkowski: Application of laser scanners to determine the shape of mine excavations for safety assessment, using the example of the cross-cut Mina in the salt mine Wieliczka, Reports on Geodesy No. 2(87), pp. 239-250, Warszawa, (2009)

9. A. Maj: Wypiętrzanie terenu pod wptywem zmian warunków hydrogeologicznych na przykładzie skutków zamknięcia wycieku w poprzeczni Mina w kopalni soli Wieliczka, Prace Instytutu Mechaniki Górotworu PAN, t. 14, nr 1-4, s. 103-111, Instytut Mechaniki Górotworu PAN, (2012)

10. A. P. Rinaldi, J. Rutqvist: Modeling of deep fracture zone opening and transient ground surface uplift at $\mathrm{KB}-502 \mathrm{CO}_{2}$ injection well, In Salah, Algeria, International Journal of Greenhouse Gas Control, vol. 12, pp. 155-167, January (2013) 